\title{
Infective Endocarditis as the Cause of Death: A \\ Population-based Study in Portugal, from 2002 to 2018
}

\section{Endocardite Infecciosa Como Causa de Morte: Um Estudo Populacional em Portugal, de 2002 a 2018}

\author{
Catarina de SOUSA $\triangle^{1,2}$, Ruy M. RIBEIRO ${ }^{3}$, Fausto J. PINTO ${ }^{1,4}$ \\ Acta Med Port 2021 Dec;34(12):833-841 - https://doi.org/10.20344/amp.14609
}

\section{ABSTRACT}

Introduction: Infective endocarditis presents a high rate of morbidity and mortality. Population-based studies addressing mortality caused by infective endocarditis in Portugal are scarce. We aimed to study deaths caused by Infective endocarditis, as well as corresponding demographics and temporal trends.

Material and Methods: Retrospective cohort study of all patients whose main cause of death was Infective endocarditis in Portugal from 2002 to 2018. The data was obtained from the national death certificate information system.

Results: In Portugal, 3634 people died from infective endocarditis throughout the 17-year study period - infective endocarditis specific mortality rate of 2.1 per 100000 habitants. Of all deceased, $89 \%$ were at least 60 years old, and most were women (55\%). Overall, $72 \%$ died in a healthcare institution. An annual $9 \%$ increase in the incidence death rate from Infective endocarditis was observed, with a significant upward trend during the colder months.

Discussion: In Portugal, mortality by infective endocarditis increased, mainly affecting older patients and women, and which can partially be explained by factors such as ageing of the population. The management of older patients with infective endocarditis is challenging as they present a higher number of comorbidities, more valvular heart disease and valve implants, invasive medical procedures and are less likely to undergo cardiac surgery.

Conclusion: In addition to data on the evolution of demographics in Portugal, it is crucial to study the incidence of infective endocarditis over time to help explain these findings. The identification of factors that can be used to better model national health policies to improve clinical outcomes of infective endocarditis in Portugal is also required.

Keywords: Endocarditis/epidemiology; Endocarditis/mortality; Portugal; Seasons

\section{RESUMO}

Introdução: A endocardite infeciosa apresenta uma taxa substancial de morbilidade e mortalidade. Estudos populacionais que abordam a mortalidade por endocardite infeciosa em Portugal são escassos. O nosso objetivo foi estudar as mortes causadas por endocardite infeciosa e os dados demográficos e tendências temporais correspondentes.

Material e Métodos: Estudo de coorte retrospetivo de todos os doentes cuja causa de óbito foi endocardite infeciosa em Portugal entre 2002 e 2018. Os dados foram obtidos no sistema nacional de informação de certificados de óbito.

Resultados: Em Portugal, 3634 pessoas morreram de endocardite infeciosa ao longo de um período de 17 anos - taxa de mortalidade específica da endocardite infeciosa de 2,1 por 100000 habitantes. De todos os falecidos, $89 \%$ tinham pelo menos 60 anos, a maior parte dos quais do género feminino (55\%) e morreram por endocardite infeciosa. Globalmente, $72 \%$ morreram numa instituição de saúde. Foi demonstrado um aumento anual de $9 \%$ na taxa de mortalidade por endocardite infeciosa, com uma tendência ascendente significativa nos meses mais frios.

Discussão: Em Portugal, a mortalidade por endocardite infeciosa aumentou, afetando principalmente doentes mais idosos e mulheres, o que pode ser parcialmente explicado pelo envelhecimento da população. O manejo de doentes idosos com endocardite infeciosa é exigente, pois apresentam maior número de comorbidades, mais valvulopatia e próteses valvulares, procedimentos médicos invasivos e menor probabilidade de serem submetidos a cirurgia cardíaca.

Conclusão: Para além dos dados sobre a evolução demográfica de Portugal, é indispensável rever a incidência da endocardite infeciosa e a sua tendência, de forma a melhor interpretar estes resultados. É fundamental identificar indicadores que possam ser usados para melhor modelar as políticas nacionais de saúde, de forma a melhorar os resultados clínicos na endocardite infeciosa no nosso país.

Palavras-chave: Endocardite/epidemiologia; Endocardite/mortalidade; Estações; Portugal

\section{INTRODUCTION}

Infective endocarditis (IE), an inflammatory process affecting the valves, endocardium and/or intracardiac prosthetic material, and is often caused by bacteria. A high incidence of morbidity and mortality related to complicated IE has been described. ${ }^{1}$

Worldwide, IE has an estimated annual incidence rate of

3 - 10 per 100000 people. $^{2}$ Several studies ${ }^{3-6}$ reported an increasing incidence over time. This is likely due to an ageing population, as well as other factors such as a higher prevalence of structural valve disease, prosthetic valves or intracardiac devices and comorbidities (diabetes, hemodialysis, HIV) or a high rate of invasive medical procedures.

1. Centro Cardiovascular da Universidade de Lisboa (CCUL). Faculdade de Medicina. Universidade de Lisboa. Lisboa. Portugal.

2. Serviço de Cardiologia. Centro Hospitalar Barreiro/Montijo (CHBM). Barreiro. Portugal.

3. Laboratório de Biomatemática. Instituto de Saúde Ambiental. Faculdade de Medicina. Universidade de Lisboa. Lisboa. Portugal.

4. Departamento Coração e Vasos. Centro Hospitalar e Universitário Lisboa Norte (CHULN). Lisboa. Portugal.

$\square$ Autor correspondente: Catarina Sousa. catarinasousacardio@gmail.com

Recebido: 21 de julho de 2020 - Aceite: 24 de janeiro de 2021 - First published: 08 de março de 2021 - Online issue published: 02 de dezembro de 2021 Copyright @ O Ordem dos Médicos 2021 
Despite improvement in diagnosis and medical/surgical treatment, most centers report an intrahospital mortality around $20 \% .^{7}$ Indeed, multiple series have reported an increasing trend for this indicator in several developed countries such as France, ${ }^{5}$ Italy ${ }^{4}$ or England. ${ }^{8}$ On the other hand, Finland ${ }^{9}$ and Sweden ${ }^{10}$ showed no significant changing trends, while Toyoda et $a^{6}{ }^{6}$ concluded that the mortality rate due to IE decreased in the United States of America between 1998 and 2013. Nevertheless, intrahospital mortality for IE is high, as reported in international series with $12.6 \%$ in the Euro Heart Survey, ${ }^{11} 18 \%$ in the ICE study, ${ }^{12}$ or $17.1 \%$ in the recent EURO-ENDO registry. ${ }^{13}$

Portugal has had a significant reduction in the mortality attributed to cardiovascular disease ${ }^{14}$ in all age groups in the last 20 years, predominantly related to a reduction in death attributed to ischemic heart disease. However, there is scarce data available regarding IE-related mortality. ${ }^{15}$

In this study, we aimed to address this lack of data in Portugal, with a population-based analysis involving fatal IE and to specifically evaluate temporal trends, age and gender differences.

\section{MATERIAL AND METHODS \\ Study design and data source}

A nationwide retrospective observational study on fatal IE was performed using data from the National Institute of Statistics (Instituto Nacional de Estatística - INE) in Portugal, from January 2002 to December 2018. All data used in this study is publicly available and was obtained directly from the INE's internet portal (https://www.ine.pt/xportal/ xmain?xpgid=ine_main\&xpid=INE\&xlang=pt) or through the use of the email info@ine.pt for data request.

This data is based on information used for statistical purposes from the Civil Registry Integrated System (Sistema Integrado do Registo e Identificação Civil - SIRIC) and the Death Certificate Information System (Sistema de Informação dos Certificados de Óbito - SICO), covering all deaths, residents and non-residents, occurring in the country.

The death certificate is mandatory by law and is issued by a trained physician identifying the main cause of death and other secondary clinical diagnoses that contributed to death. For the studied period, only the basic clinical diagnosis causing death ("illness or injury that initiated the chain of pathological events that led to death or the circumstances of the accident or violence that produced the fatal injury") could be collected.

After 2002, the coding of causes of death according to the International Statistical Classification of Diseases and Related Health Problems, $10^{\text {th }}$ Revision (ICD-10) version has been used and is carried out by the Portuguese Directorate-General of Health. ${ }^{16}$

For the identification of IE as the cause of death, we used codes I33, I38 and I39 (ICD-10).

\section{Study population and variables}

The population in each year was obtained from census population (2001 and 2011) and from estimates for intercensal years, at INE's database. The estimated population was 10444592 in 2002, increasing to 10573479 in 2009 and decreasing to 10276617 in $2018 .{ }^{17}$

Portuguese national all-cause mortality data for the period 2002 - 2018 was also obtained from INE, ${ }^{18}$ the number of deaths varied between 102363 (2006) and 113573 (2018), with the crude mortality rate varying between 9.69 (2006) and 10.99 (2018) per 1000 habitants.

All deaths caused by IE were assessed and stratified by gender and age groups (20-year interval groups, 0 - 19, 20 - 39, 40 - 59, $60-79$, $\geq 80$ ). Death location (healthcare institution vs home) was also collected, as well as data on whether medical autopsy was carried out.

The following indicators were analyzed: proportion of deaths with IE as cause of death (\% of total deaths by specific cause); gender; location of death (healthcare institution vs home); crude death rate by gender and 20-year interval age groups; standardized mortality rate (all ages) for the European 2013 standard population ${ }^{19}$ performed by the direct method. ${ }^{20}$

The study used anonymized public domain data and therefore ethics committee approval was not required.

\section{Statistics}

Continuous variables are presented as mean \pm standard deviation and categorical variables expressed as frequencies and percentages. We assessed the trends in annual death rate standardized to the 2013 census population.

To assess temporal trends and the effect of age, gender and seasonality, we compared different regression models, including Poisson, negative binomial and corresponding zero-inflation regression models. We used Akaike's information criteria to compare different model structures and likelihood ratio tests to compare nested models with different covariates. ${ }^{21}$ We used 'age group', gender', 'month' and 'season' as potential covariates. The regression results are presented using rate ratios and corresponding 95\% confidence intervals $(\mathrm{Cl})$.

The data was analyzed using IBM SPSS Statistics for Windows version 24, except for the regression models that were done with $R,{ }^{22}$ with the following packages MASS ${ }^{22}$ for the negative binomial models and $\mathrm{pscl}^{23}$ for zero-inflated models.

\section{RESULTS}

Demographic features of patients who died of IE in Portugal

From 2002 to 2018, IE was documented as the cause of death in 3634 patients. Demographic data is depicted in Table 1.

Fatal cases of IE were lowest in the group $\leq 19$ years old and increased with increasing patient age, with $89 \%$ of the deaths occurring in individuals 60 years old and older.

A growing number of deaths among patients with at least 60 years of age was noted throughout the 17-year study period, with a higher increase noted from 2010 
Table 1 - Demographic characteristics of patients with fatal IE between 2002- 2018, in Portugal

\begin{tabular}{lc}
\hline Characteristics & $\mathbf{n}(\%)$ \\
\hline Gender & $1624(44.7)$ \\
Male & $2010(55.3)$ \\
Female & \\
Age (years) & \\
$\leq 19$ & $2(0.05)$ \\
$20-39$ & $66(1.8)$ \\
$40-59$ & $316(8.7)$ \\
$60-79$ & $1534(42)$ \\
$\geq 80$ & $1715(47)$ \\
ICD 10 & \\
I33 - Acute and subacute endocarditis & $734(20.2)$ \\
I38 - Non specified valve endocarditis & $2899(79.8)$ \\
I39 - Endocarditis and valve changes & $1(0.0)$ \\
\hline * One case of unknown age
\end{tabular}

onwards in patients 80 years old and over, exceeding those aged 60 - 79 years old (Fig. 1).

Of the total deaths, $1624(44.7 \%)$ were males (M) and $2010(55.3 \%)$ were females $(F)$ and the ratio male/female was on average 0.84 ( $\min .0 .62$ - max. 1.1) per year, during the study period.

Among individuals 60 years of age and older, there were more female than male deaths, while the opposite was noted amongst younger patients (Fig. 2).

\section{Mortality by IE in Portugal}

IE was responsible on average for 2 out of 1000 deaths in Portugal, during the study period.
The standardized mortality (using the European 2013 standard population) rate due to IE in Portugal was on average 2.1 per 100000 habitants, with an increasing trend for the period analyzed from 1.0 (2002) to 3.8 (2018) per 100 000 habi-tants (Fig. 3).

The proportion of deaths per IE to the total number of deaths of circulatory disease increased from 0.3 in 2002 to 1.2 in 2018 . These results were driven by a reduction in the total number of deaths resulting from circulatory diseases in general (mortality rate due to circulatory diseases was 391 per 100000 habitants in 2002 and decreased to 318 per 100000 habi-tants in 2018), in line with an increase in the number of deaths by IE in the same period (Table 2).

Additionally, considering all years, men had a lower mortality rate for IE (1.9) than female patients (2.2). However, this difference between male and female patients only became clear over the last decade (Fig. 4 and Table 2).

IE specific mortality rate was lower in younger patients and increased gradually with age (Table 3 ). Comparing deaths caused by IE with total deaths in the Portuguese population, the highest contribution of IE was in the group 60 - 79 years old, decreasing slightly in patients over 80 years old.

\section{Mortality according to place of death}

Analysis on the place of death indicates that $71.9 \%$ died in a healthcare institution and $22.9 \%$ died at home. The remaining $5.2 \%$ of cases did not have information on place of death. Regardless of the place, the percentage of death in women was higher (this difference was more pronounced when considering deaths at home) than in men. Across all age groups, deaths in healthcare institutions were more prevalent (Fig. 5).

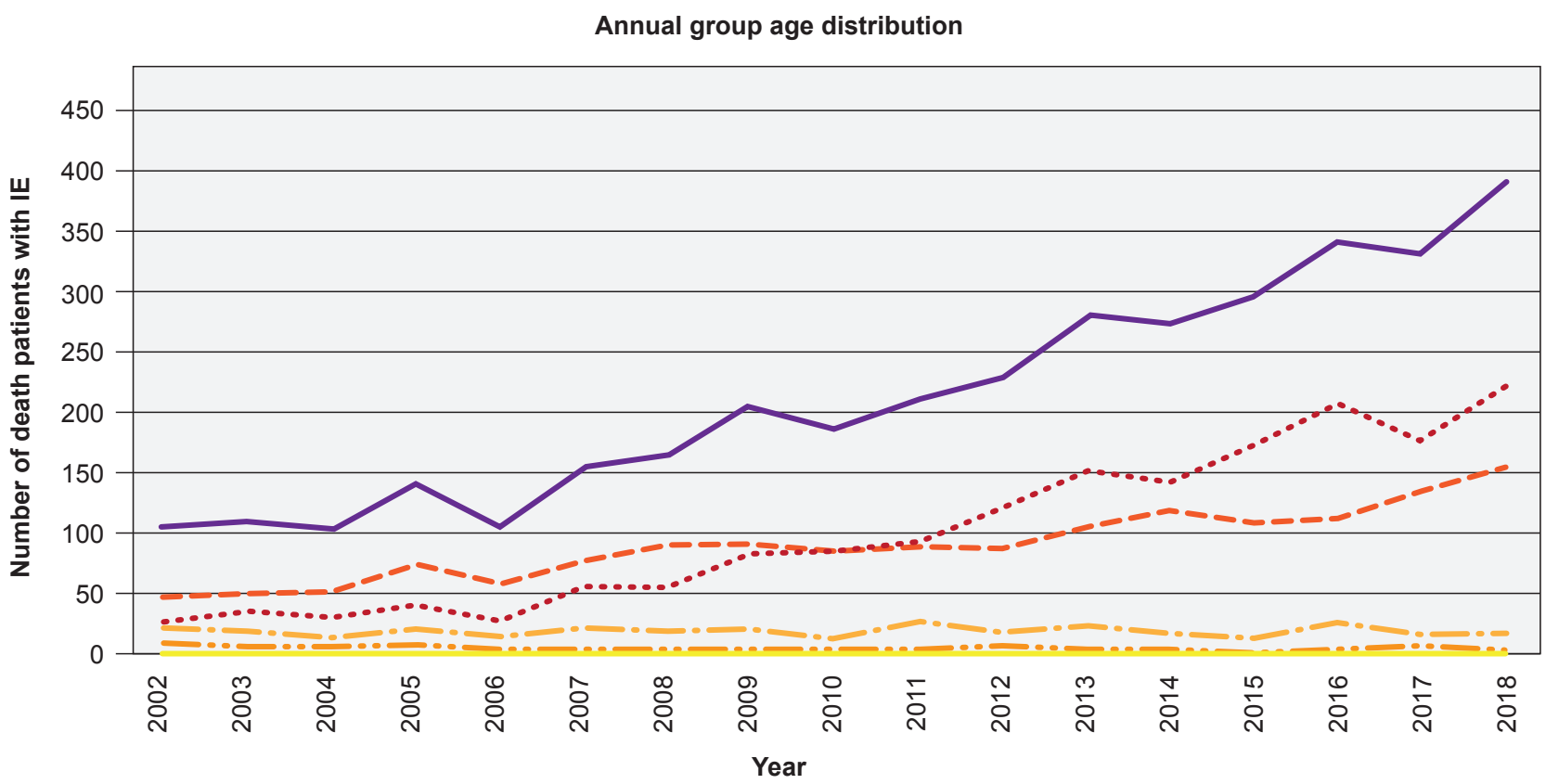

Total $0-19$ $-\cdot-20-39$

Figure 1 - Distribution of fatal IE cases by age group from 2002 to 2018 


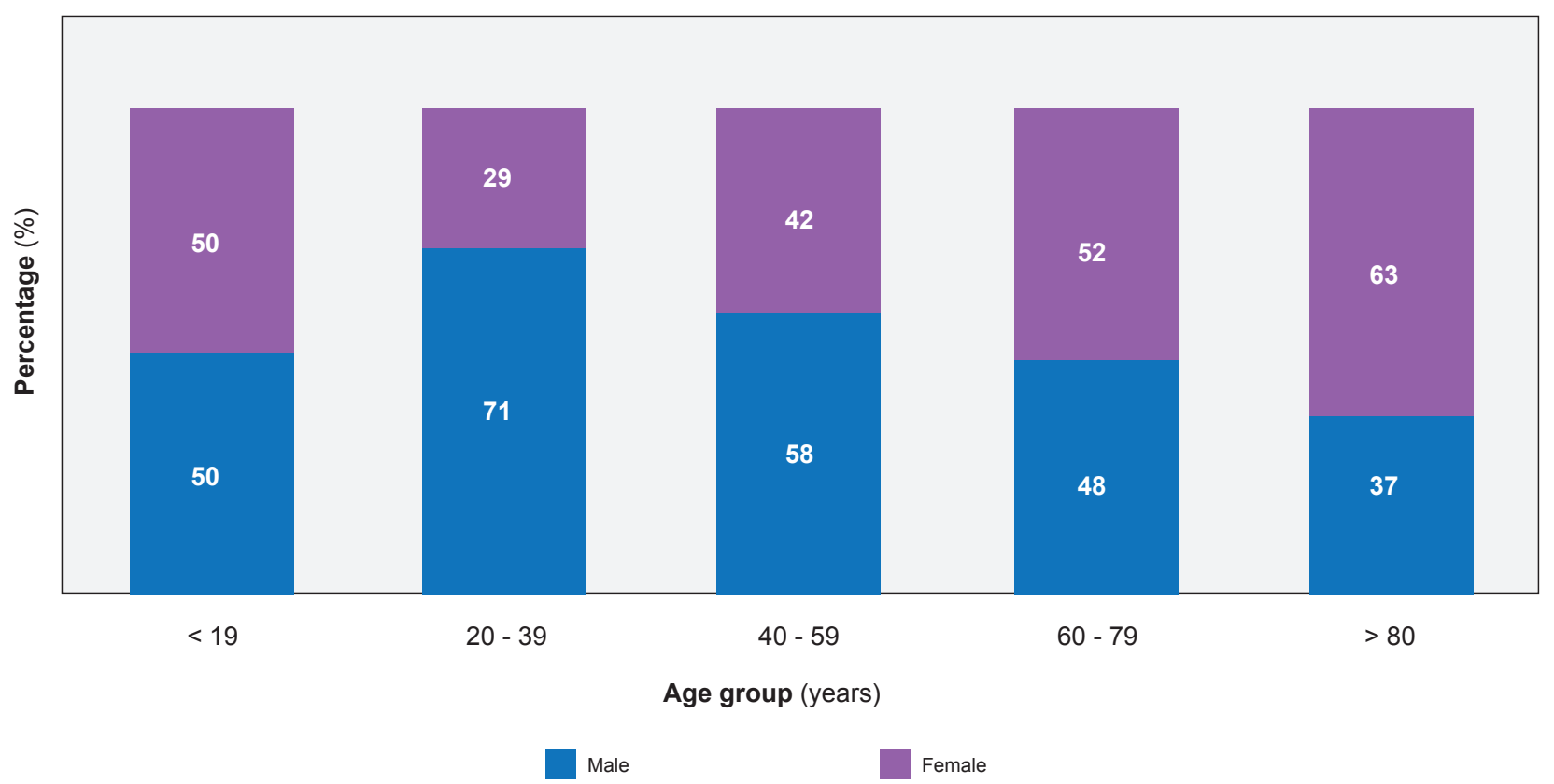

Figure 2 - Distribution of patients with fatal IE according to age and gender

Medical autopsy confirming the diagnosis was available only for 104 death certificates (2.9\% of the total cohort).

\section{Temporal and seasonal effects on the deaths by IE}

To study the evolution of the number of deaths due to IE in Portugal, we tested different model structures (see Methods) with the dependent variable 'number of deaths' each month from 2002 to 2018 . We evaluated the temporal trend over that period, as well as the effect of gender, age group and season. The best model structure was a negative binomial, although a Poisson regression model gave essentially the same rate ratio estimates. To analyze the effect of season, we first used a preliminary model with 'month' as covariate. We found that the number of deaths increased in December, January, February and March, compared with the other months. Therefore, we defined two 'seasons': a winter period including those months, and the rest of the year. This shorter model was as good as the full model with individual months. The results of this regression are presented in Table 4.

The final variables included in the model, 'year', 'age group', 'gender' and 'season', were all highly significant and models without any one of these were statistically inferior, using a likelihood ratio test. We found an approximate $9 \%$

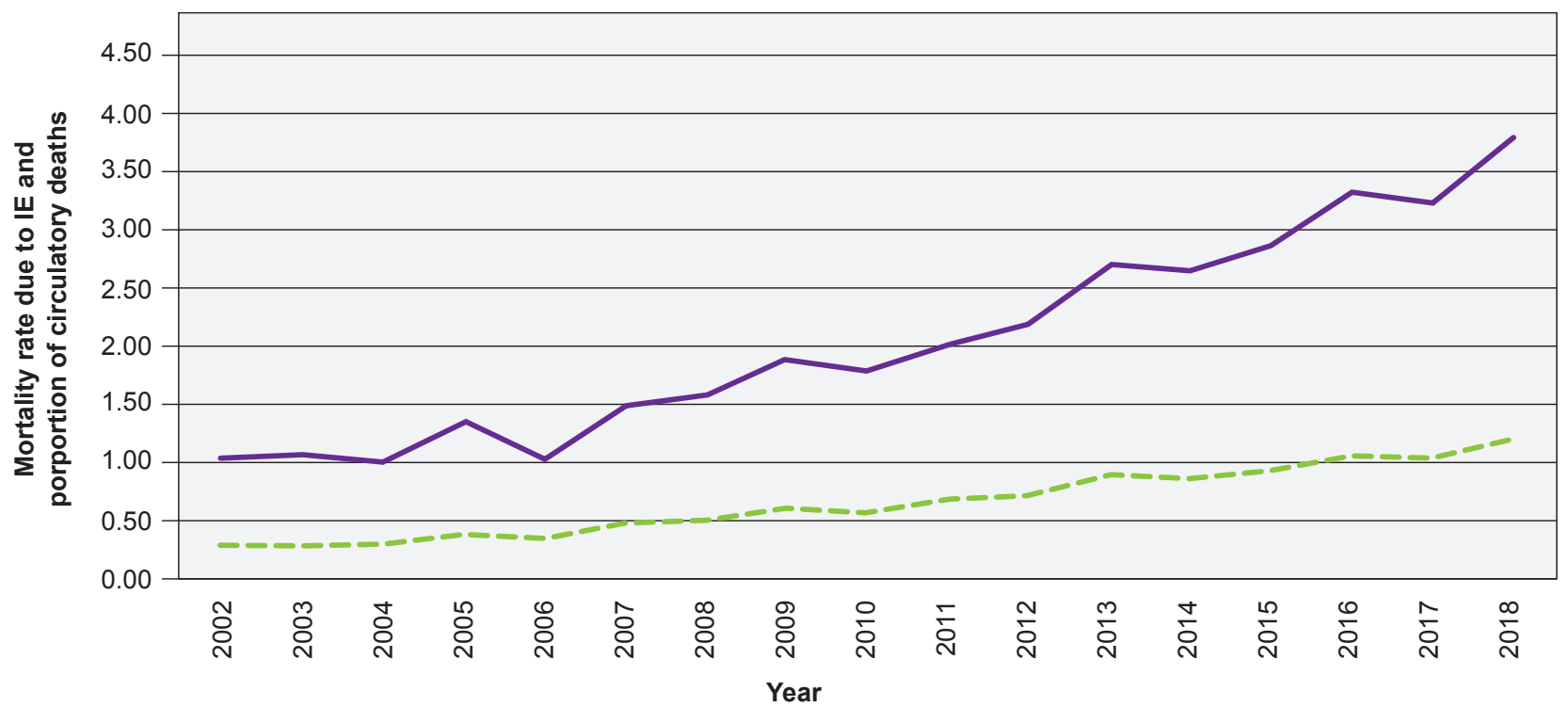

Figure 3 - Evolution of deaths due to IE in Portugal from 2002 to 2018. Standardized mortality rate (per 100 000) (purple line) and proportion of deaths (\%) that are due to IE in relation to all circulatory diseases (green - dashed line). 
Table 2 - Total and gender specific mortality (absolute and rate) by infective endocarditis between 2002 and 2018, in Portugal

\begin{tabular}{|c|c|c|c|c|c|c|c|c|c|}
\hline Year & $\begin{array}{l}\text { Number } \\
\text { of deaths } \\
\text { by IE }\end{array}$ & $\begin{array}{l}\text { Mortality } \\
\text { rate for IE* }\end{array}$ & $\begin{array}{l}\text { Number of } \\
\text { deaths by } \\
\text { circulatory } \\
\text { causes }\end{array}$ & $\begin{array}{l}\text { Mortality rate } \\
\text { for circulatory } \\
\text { causes }^{*}\end{array}$ & $\begin{array}{c}\text { Proportion } \\
\text { deaths by IE } \\
\text { to circulatory } \\
\text { causes }\end{array}$ & $\begin{array}{l}\text { Number } \\
\text { of deaths } \\
\text { by IE } \\
\text { (male) }\end{array}$ & $\begin{array}{c}\text { Male } \\
\text { specific } \\
\text { mortality } \\
\text { rate by IE* }\end{array}$ & $\begin{array}{l}\text { Number } \\
\text { of deaths } \\
\text { by IE } \\
\text { (female) }\end{array}$ & $\begin{array}{c}\text { Female } \\
\text { specific } \\
\text { mortality } \\
\text { rate by IE* }\end{array}$ \\
\hline 2002 & 106 & 1.01 & 40846 & 391.07 & 0.26 & 48 & 0.95 & 58 & 1.07 \\
\hline 2003 & 110 & 1.05 & 40893 & 390.46 & 0.27 & 59 & 1.17 & 51 & 0.94 \\
\hline 2004 & 106 & 1.01 & 36983 & 352.40 & 0.29 & 51 & 1.01 & 55 & 1.01 \\
\hline 2005 & 141 & 1.34 & 36570 & 347.89 & 0.39 & 61 & 1.21 & 80 & 1.47 \\
\hline 2006 & 108 & 1.03 & 32872 & 312.10 & 0.33 & 54 & 1.07 & 54 & 0.99 \\
\hline 2007 & 154 & 1.46 & 34103 & 323.15 & 0.45 & 69 & 1.36 & 85 & 1.55 \\
\hline 2008 & 165 & 1.56 & 33642 & 318.49 & 0.49 & 82 & 1.62 & 83 & 1.51 \\
\hline 2009 & 199 & 1.88 & 33314 & 315.07 & 0.60 & 88 & 1.74 & 111 & 2.01 \\
\hline 2010 & 189 & 1.79 & 33693 & 318.68 & 0.56 & 88 & 1.74 & 101 & 1.83 \\
\hline 2011 & 210 & 1.99 & 31565 & 299.41 & 0.67 & 97 & 1.92 & 113 & 2.05 \\
\hline 2012 & 230 & 2.19 & 32761 & 312.39 & 0.70 & 105 & 2.09 & 125 & 2.27 \\
\hline 2013 & 280 & 2.69 & 31421 & 301.33 & 0.89 & 119 & 2.39 & 161 & 2.94 \\
\hline 2014 & 275 & 2.65 & 32134 & 309.73 & 0.86 & 126 & 2.55 & 149 & 2.73 \\
\hline 2015 & 296 & 2.86 & 32275 & 312.10 & 0.92 & 114 & 2.32 & 182 & 3.34 \\
\hline 2016 & 343 & 3.33 & 32628 & 316.48 & 1.05 & 150 & 3.07 & 193 & 3.55 \\
\hline 2017 & 332 & 3.23 & 32180 & 312.70 & 1.03 & 140 & 2.87 & 192 & 3.54 \\
\hline 2018 & 390 & 3.80 & 32732 & 318.51 & 1.19 & 173 & 3.56 & 217 & 4.00 \\
\hline
\end{tabular}

*Per 100000 persons

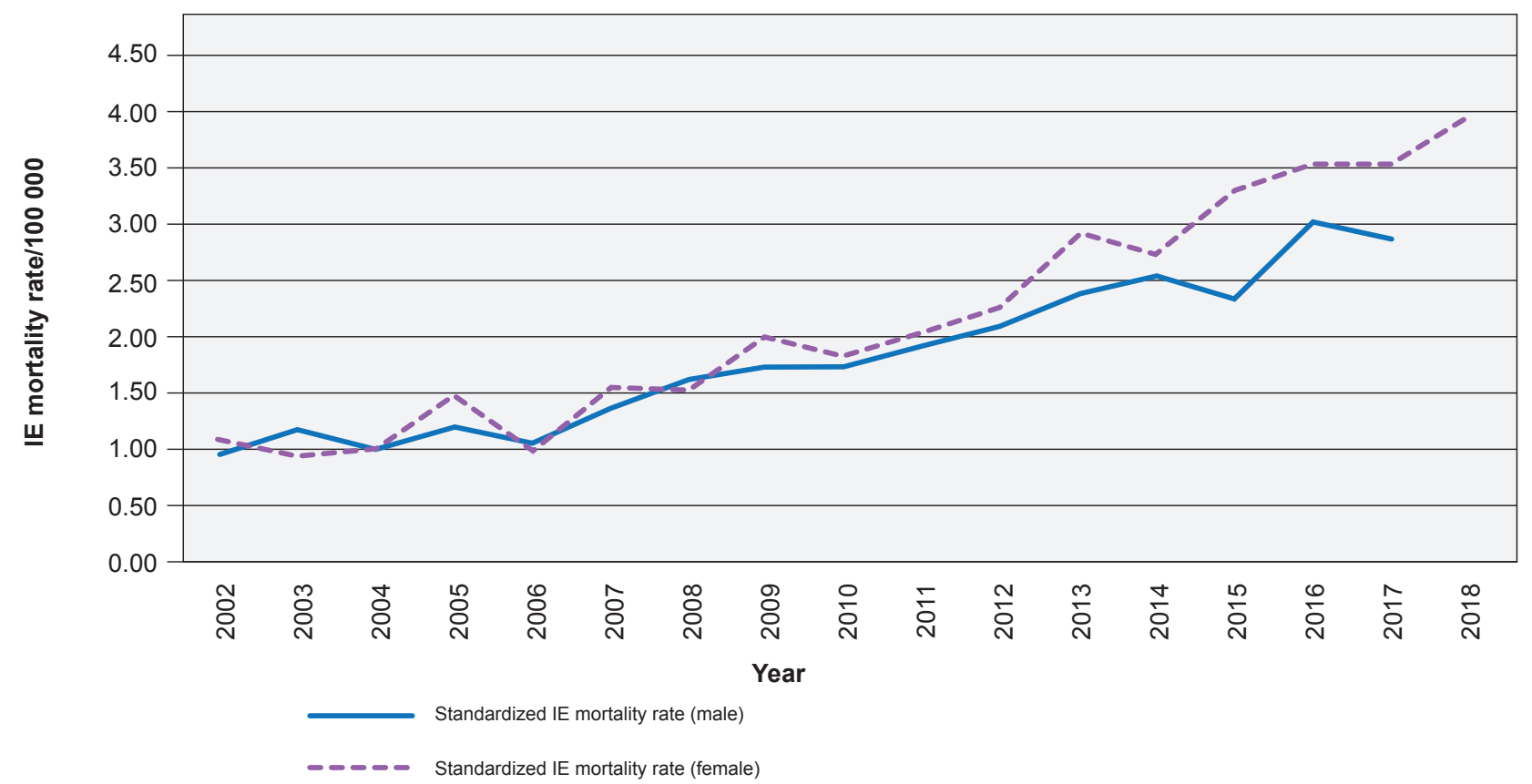

Figure 4 - Evolution from 2002 to 2018 of specific cause of death (IE) standardized mortality rate by gender in Portugal

increase in incidence per year, since 2002. This estimate had very narrow confidence intervals. Women had a $19 \%$ higher incidence of death compared to men. The incidence increased substantially with older age groups, and this was very significant, despite wide confidence intervals in these estimates. Finally, we found a lower incidence (of approximately $20 \%$ ) during the warmer months of the year, from
April to November.

\section{DISCUSSION}

This is the first nationwide study analyzing deaths associated with IE in Portugal and four main findings were obtained from this analysis. First, the standardized mortality rate for IE was 2.1 per 100000 inhabitants, with an 
Table 3 - Age specific proportion of deaths caused by IE per total number of deaths and IE mortality rate

\begin{tabular}{cccc}
\hline Age group & $\mathbf{n}$ & Proportion IE deaths per total deaths $\left({ }^{*} \mathbf{1 0 0}\right)$ & Age specific IE mortality rate* $^{*}$ \\
\hline$\leq 19$ & 2 & 0.02 & $<0.0001$ \\
$20-39$ & 66 & 0.17 & 0.13 \\
$40-59$ & 316 & 0.18 & 0.64 \\
$60-79$ & 1534 & 0.24 & 4.30 \\
$\geq 80$ & 1715 & 0.18 & 17.92 \\
\hline
\end{tabular}

*Per 100000 persons per year

annual increasing trend. Second, most deaths occurred in patients who were at least 60 years old. Third, there were more deaths of female patients than male patients. Finally, mortality by IE was higher during the colder months.

The overall IE standardized mortality rate increased steadily from 1 to 3.8 per 100000 people over the period of the study, 2002 to 2018. Data obtained from Instituto Nacional de Estatística revealed a consistent increase in IE specific mortality over this period, with an annual increase averaging about $9 \%$. As a comparison, IE incident death rate in Finland ${ }^{24}$ was lower (1.42 per 100000 habitants) and there was no significant changing trend between 2004 and 2016. The incidence of IE in Portugal has not been estimated, and if it is increasing, it could be an important aspect helping to explain the increase seen in mortality. This is especially important, because nationwide studies from Denmark ${ }^{25}$ and Italy ${ }^{4}$ have shown an increasing incidence of IE, which could impact on mortality. This increased incidence could be explained by several factors including ageing of the population, a higher use of intracardiac devices, cardiac valve prosthesis implantation and invasive medical procedures in a population with more comorbidities. A more debilitated population with IE could account for an increase in deaths by this disease. Likewise, the present analysis included a timeframe with significant changes in IE prophylaxis, improvement in IE diagnosis with newer techniques (improved microbiologic detection, 3D echocardiography and PET/CT imaging) and surgical intervention timing ${ }^{26}$ that could have impacted on the mortality of these patients. Note that a dramatic decrease in Portugal's cardiovascular disease mortality and years of life lost has been demonstrated $^{27,28}$ (this is due to diagnostic and therapeutic improvements of ischemic heart disease and cerebrovascular disease), which translated in a decrease in mortality due to circulatory diseases in the studied period, contrasting with an increasing trend in the mortality by endocarditis.

Despite deaths caused by IE occurring in all considered age groups, almost $90 \%$ of the deceased were 60 years old or older, which is in agreement with other series ${ }^{4,12,13,29-32}$ and from 2010 onwards octogenarians were in fact the most prevalent age-group. The elderly present more comorbidities, more heart valve disease and valve implants, ${ }^{33,34}$ are subject to more invasive medical procedures, are less likely to undergo cardiac surgery ${ }^{35}$ and age has been shown to be an independent risk factor for mortality ${ }^{36}$ in IE.

All these findings could partly be explained by Portuguese demographic trends. Indeed, the population in Portugal has experienced a gradual increase in life expectan$\mathrm{cy}^{37,38}$ with a sustained increase in the aging index of the population, ${ }^{39}$ with concomitant exacerbation of the comorbidities due to population aging.

Worldwide, in population-based studies of incident IE, ${ }^{40}$ men are usually more affected. Paradoxically, in our study, women who have a higher life expectancy ${ }^{37}$ (in Portugal, women live on average six years longer than men) and are also in greater number in the Portuguese population, ${ }^{17}$ had a higher mortality in the setting of IE with a ratio male/female varying between 0.6 and 1.1 - this comparison is more pronounced in older patients (over 60 years of age). This is probably explained by the fact that gender may, indeed, be an additional risk factor for IE mortality. ${ }^{13,32,41}$ Moreover, gender variations regarding comorbidities, frailty index, treatment biases and physiologic differences may explain this contradictory finding. ${ }^{42}$

Nearly $3 \%$ of patients that died due to IE underwent a medical autopsy - indeed, autopsy continues to be an
A

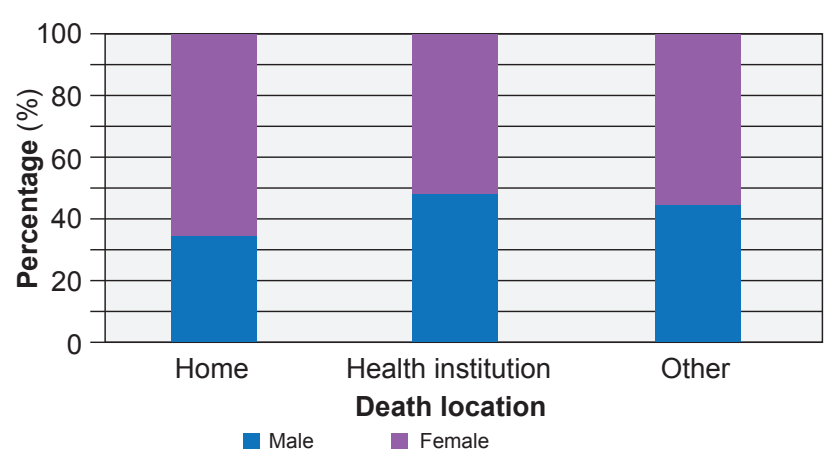

B

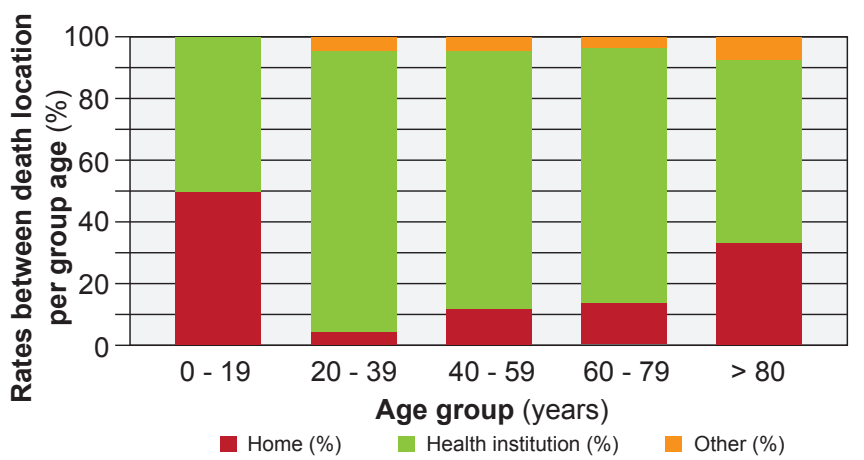

Figure 5 - Distribution of patients concerning death location according to gender (A) and age group (B) 
Table 4 - Results of negative binomial regression for the number of monthly deaths

\begin{tabular}{|c|c|c|c|c|}
\hline Variable & Rate ratio & Lower limit & Upper limit & $p$-value \\
\hline Baseline & 0.048 & 0.036 & 0.065 & \\
\hline Year* & 1.086 & 1.077 & 1.094 & $<0.00001$ \\
\hline Age $[0,39]$ & 1 & & & $<0.00001$ \\
\hline$[40,59]$ & 9.4 & 7.3 & 12.4 & \\
\hline$[60,79]$ & 45.5 & 35.9 & 58.8 & \\
\hline$\geq 80$ & 48.7 & 38.4 & 62.9 & \\
\hline Gender Male & 1 & & & $<0.00001$ \\
\hline Female & 1.19 & 1.10 & 1.28 & \\
\hline Season† & 1 & & & $<0.00001$ \\
\hline & 0.797 & 0.737 & 0.862 & \\
\hline
\end{tabular}

* Year is coded as a continuous variable from 1 to 17 , corresponding to 2002 to 2018 ; † The reference season is from December to March.

important tool in identifying clinically missed IE and in unveiling the multisystemic involvement and complications that may emerge from IE. Nevertheless, hospital series report fatal IE cases in $1 \%-1.5 \%$ of autopsies, ${ }^{43,44}$ meaning that only a minor fraction of cases are diagnosed after death occurs. Despite a paucity of data regarding the frequency which IE is found in autopsies, ${ }^{44}$ it is a crucial method of clinical research. Nearly $23 \%$ of subjects died at home, which is unexpected as IE is a complex disease with almost universal hospitalization, and the number of autopsies is clearly lower than this rate. Newly diagnosed fatal IE with sudden death identified in an autopsy is one explanation. Data concerning previous hospitalization, or the treatment regimen, was not available and therefore the reasons that could potentially explain the remaining cases are speculative. Still, this finding could be related to patients with a very recent hospitalization for acute IE, on outpatient parenteral antibiotic course, or waiting for cardiac surgery, or in patients that were referred for palliative care.

A 2017 meta-analysis ${ }^{45}$ including twenty five observational studies, estimated short and long term follow-up (six months up to 10 years) mortality rate of $20 \%$ and $37 \%$, respectively. Data on long term outcomes of IE in populationbased and observational studies are limited - the 5-year mortality rate described by Fernandez-Hidalgo et $a^{46}$ and Toyoda et $a^{47}$ was around $50 \%$. Alarmingly, long-term outcomes have shown to be poor, even in patients who have survived and have been discharged from hospital after an IE event. ${ }^{48}$ This may probably explain why we have found that one fifth of deaths occurred outside a healthcare institution. Other factors that could partially contribute to this high rate is the diagnosis of IE through autopsy in deaths occurring outside a hospital.

Finally, there is scarce data on the impact of seasonal variation on deaths for IE. ${ }^{49}$ Indeed, seasonal mortality variation has been described in other conditions such as heart failure, ${ }^{50,51}$ sepsis, ${ }^{52}$ cardiovascular and all-cause mortality. ${ }^{53,54}$ In our study, a $20 \%$ mortality decrease was noted during the warmer months. Reasons for this result remain speculative, but should take into account not only exposure to cold, but also socio-economic conditions, ${ }^{55}$ or immunologic response with cold temperatures related to melatonin secretion ${ }^{56}$ and leukocyte function. ${ }^{57}$ Finkelhor ${ }^{58}$ detected a higher fall/winter predominance of the diagnosis of IE with echocardiography, with an impact on incidence and, possibly, mortality as well.

\section{Limitations of the study}

One must consider that this is a retrospective study based on administrative data using coded information. Reliable and uniform diagnosis is always an issue. Coding errors could also have occurred, and there is no possibility to review clinical data, case by case. Nevertheless, death certificates are issued by trained physicians, which guarantees the quality of the presented data. Furthermore, no data exists concerning the population with IE and its characteristics such as demographics, comorbidities, microbiology, procedures or surgical interventions that could help explain our findings regarding mortality rate and its temporal trends. Additionally, codes 138 and 139 can include non-infective forms of IE such as Libmann-Sachs. Finally, as previously mentioned, there is currently no published data on the incidence of IE incidence in Portugal, which would be crucial for this discussion.

\section{CONCLUSION}

IE has a mortality rate estimated at 2.1 per 100000 people, with an increasing trend of around $9 \%$ annually. A seasonal variation was noted, with increased mortality in the colder months. The association of IE with death was more significant in older patients, particularly in those aged 60 years old or older, and women had a higher IE specific mortality rate. Portuguese demographic features can partially explain the observed outcomes. Further analysis of the epidemiology of IE in Portugal, especially incidence of the disease, previous comorbidities and demographics of the patients, as well as other socio-economic factors such as level of education and income would be crucial to expand our understanding of these findings.

\section{AUTHORS CONTRIBUTION}

All the authors had similar contributions for the methodology, data analysis, draft of the paper and critical review. 


\section{ACKNOWLEDGEMENTS}

The authors would like to thank the Instituto Nacional Estatística for providing Portuguese demographic data and IE specific mortality data. The authors also acknowledge the reviewers' suggestions that improved the manuscript.

\section{PROTECTION OF HUMANS AND ANIMALS}

The authors declare that the procedures were followed according to the regulations established by the Clinical Research and Ethics Committee and to the Helsinki Declaration of the World Medical Association updated in 2013.

\section{REFERENCES}

1. Habib G, Lancellotti P, Antunes M, Bongiorni M, Casalta JP, Del Zotti F, et al. 2015 ESC guidelines for the management of infective endocarditis. Eur Heart J. 2015;36:3075-128.

2. Cahill T, Prendergast B. Infective endocarditis. Lancet. 2016;387:88293.

3. Heredia-Rodríguez M, Hernández A, Bustamante-Munguira J, Álvarez F, Eiros J, Castrodeza J, et al. Evolution of the incidence, mortality, and cost of infective endocarditis in Spain between 1997 and 2014. J Gen Intern Med. 2018:33:1-4.

4. Cresti A, Chiavarelli M, Scalese M, Nencioni C, Valentini S, Guerrini F, et al. Epidemiological and mortality trends in infective endocarditis, a 17-year population-based prospective study. Cardiovasc Diagn Ther. 2017;7:27-35.

5. Thuny F, Giorgi R, Habachi R, Ansaldi S, Le Dolley Y, Casalta J, et al. Excess mortality and morbidity in patients surviving infective endocarditis. Am Heart J. 2012;164:94-101.

6. Toyoda N, Chikwe J, Itagaki S, Gelijns A, Adams D, Egorova N. Trends in infective endocarditis in California and New York State, 1998-2013. J Am Med Assoc. 2017;317:1652-60.

7. Thuny F, Grisoli D, Collart F, Habib G, Raoult D. Management of infective endocarditis: challenges. Lancet. 2012;379:965-75.

8. Mark JD, Jones S, Prendergast B, Baddour L, Lockhart P, Thornhill $M$. An increase in the incidence of infective endocarditis in England since 2008: a secular trend interrupted time series analysis. Lancet. 2015;385:1219-28.

9. Ahtela E, Oksi J, Porela P, Ekström T, Rautava P, Kytö V. Trends in occurrence and 30-day mortality of infective endocarditis in adults: population-based registry study in Finland. BMJ Open. 2019;9:e026811.

10. To A, Ternhag A, Cederstro A. A nationwide cohort study of mortality risk and long-term prognosis in infective endocarditis in Sweden. PLoS One. 2013;8:1-7.

11. Tornos P, lung B, Permanyer-Miralda G, Baron G, Delahaye F, GohlkeBärwolf $\mathrm{C}$, et al. Infective endocarditis in Europe: lessons from the euro heart survey. Heart. 2005;91:571-5.

12. Murdoch DR, Corey GR, Hoen B, Miró JM, Pappas PA, Moreillon P, et al. NIH Public Access: Clinical presentation, etiology and outcome of infective endocarditis in the 21st century: the international collaboration on endocarditis-prospective cohort study. Arch Intern Med. 2013;169:463-73

13. Habib G, Erba PA, lung B, Donal E, Cosyns B, Laroche C, et al. Clinical presentation, aetiology and outcome of infective endocarditis. Results of the ESC-EORP EURO-ENDO (European infective endocarditis) registry: a prospective cohort study. Eur Heart J. 2019;40:3222-32.

14. Nascimento BR, Brant LC, Oliveira MG, Malachias MV, Reis GM, Teixiera RA, et al. Epidemiologia das doenças cardiovasculares em países de língua. Arq Bras Cardiol. 2018;110:500-11.

15. Antunes $M$, Saraiva J. Is the role of surgery in infective endocarditis changing? Rev Port Cardiol. 2018;37:395-7.

16. Instituto Nacional de Estatística. Causas de morte -2017. 2019. [cited 2020 May 1]. Available from: https://www.ine.pt/xportal/ xmain? $x p i d=I N E \& x p g i d=i n e \_p u b l i c a c o e s \& P U B L I C A C O E S p u b \_b o u i=3$ 58633033\&PUBLICACOESmodo $=2$.

17. Instituto Nacional de Estatística. Estimativas da população residente Portugal, NUTSII, NUTS III. 2009. [cited 2020 May 5]. Available from: https://www.ine.pt/xportal/xmain?xpid=INE\&xpgid=ine publicacoes\&P UBLICACOEStipo $=$ ea\&PUBLICACOEScoleccao $=107818 \&$ PUBLICAC OEStema $=55466 \&$ selTab $=$ tab0 \&xlang $=$ pt

\section{DATA CONFIDENTIALITY}

Patients were not directly studied, and their informed consent was not deemed necessary because the data collected was retrospective and immediately anonymized.

\section{COMPETING INTERESTS}

The authors do not have any competing interests concerning the content of this article.

\section{FUNDING SOURCES}

This study has not received any public or private funding.

18. Instituto Nacional de Estatística. Óbitos $\left(\mathrm{N} .{ }^{\circ}\right)$ por local de residência (NUTS - 2013), grupo etário e sexo; Anual. INE. [cited 2020 May 5]. Available from: https://www.ine.pt/xportal/xmain?xpid=INE\&xpgid=ine indicadores\&indOcorrCod=0004204\&contexto=bd\&selTab=tab2\&xlang $=p t$.

19. Eurostat. Revision of the european standard population - Report of Eurostat's task force. Luxembourg: Eurostat; 2013. 20.

Tripepi G, Jager J, Dekker F. Stratification for confounding - Part 2 : direct and indirect standardization. Nephron Clin Pract. 2010;116:c322 5

21. Hu MC, Pavlicova M, Nunes EV. Zero-inflated and hurdle models of count data with extra zeros: examples from an hiv-risk reduction intervention trial. Am J Drug Alcohol Abuse. 2011;37:367-75.

22. Team RC. R: a language and environment for statistical computing. $R$ Foundation for Statistical Computing. Vienna, Austria. 2018. [cited 2020 May 03]. Availablefrom: https://www.R-project.org/.

23. Zeileis A, Kleiber C, Jackman S. Regression models for count data in R. J Stat Softw. 2008;27:1-25.

24. Ahtela E, Oksi J, Sipilä J, Rautava P, Kytö V. Occurrence of fatal infective endocarditis: a population-based study in Finland. BMC Infect Dis. 2019;19:1-7.

25. Erichsen $P$, Gislason $G$, Bruun N. The increasing incidence of infective endocarditis in Denmark, 1994 - 2011. Eur J Intern Med. 2016;35:95-9.

26. Habib G, Hoen B, Tornos P, Thuny F, Prendergast B, Vilacosta I, et al. Guidelines on the prevention, diagnosis, and treatment of infective endocarditis (new version 2009): The Task Force on the Prevention, Diagnosis, and Treatment of infective endocarditis of the European Society of Cardiology (ESC). Eur Heart J. 2009;30:2369-413.

27. Pereira M, Azevedo A, Lunet N, Carreira H, O'Flaherty M, Capewell S, et al. Explaining the decline in coronary heart disease mortality in Portugal between 1995 and 2008. Circ Cardiovasc Qual Outcomes. 2013;6:63442.

28. Pereira M, Peleteiro B, Capewell S, Bennett K, Azevedo A, Lunet N. Changing patterns of cardiovascular diseases and cancer mortality in Portugal, 1980-2010. BMC Public Health. 2012;12:1126.

29. Fedeli U, Schievano E, Buonfrate D, Pellizzer G, Spolaore P. Increasing incidence and mortality of infective endocarditis: a population-based study through a record-linkage system. BMC Infect Dis. 2011;11:1-7.

30. Selton-Suty C, Celard M, Le Moing V, Doco-Lecompte T, Chirouze $C$, lung B, et al. Preeminence of staphylococcus aureus in infective endocarditis: a 1-year population-based survey. Clin Infect Dis. 2012;54:1230-9.

31. Duval X, Delahaye F, Alla F, Tattevin P, Obadia J, Moing V, et al. Temporal trends in infective endocarditis in the context of prophylaxis guideline modifications three successive population-based surveys. J Am Coll Cardiol. 2012;59:1968-76.

32. Van Den Brink F, Swaans M, Hoogendijk M, Alipour A, Kelder J, Jaarsma $W$, et al. Increased incidence of infective endocarditis after the 2009 European Society of Cardiology guideline update: a nationwide study in the Netherlands. Eur Hear J Qual Care Clin Outcomes. 2017;3:141-7.

33. Nkomo V, Gardin J, Skelton T, Gottdiener J, Scott C, Enriquez-Sarano M. Burden of valvular heart diseases : a population-based study. Lancet. 2006;368:1005-11.

34. Dhawan V. Infective endocarditis in elderly patients. Clin Infect Dis. 2002;34:806-12.

35. Ramírez-Duque N, García-Cabrera E, Ivanova-Georgieva $R$, Noureddine M, Lomas JM, Hidalgo-Tenorio C, et al. Surgical treatment 
for infective endocarditis in elderly patients. J Infect. 2011;63:131-8.

36. Durante-Mangoni E. Current features of infective endocarditis in elderly patients. Arch Intern Med. 2008;168:2095.

37. Instituto Nacional de Estatistica. Tábuas de mortalidade 2014 - 2016. Informação à comunicação social. Lisboa: INE; 2017.

38. Instituto Nacional de Estatística. Projeções de população residente 2015-2080. Lisboa: INE; 2017.

39. Instituto Nacional de Estatística. Projeções de população residente 2002-2060. Lisboa: INE; 2014.

40. Scott C, Bailey K, Steckelberg J. A systematic review of populationbased studies of infective endocarditis. Chest. 2007;132:1025-35.

41. Khan M, Munir M, Khan M, Khan S, Benjamin M, Balla S. Contemporary trends in native valve infective endocarditis in united states (from the national inpatient sample database). Am J Cardiol. 2020;125:1678-87.

42. Aksoy O, Meyer L, Cabell C, Kourany W, Pappas P, Sexton D. Gender differences in infective endocarditis: Pre- and co-morbid conditions lead to different management and outcomes in female patients. Scand J Infect Dis. 2007;39:101-7.

43. Zhou Y, Wilkinson S, Cain M, Litovsky S, Reilly S. A 12-year autopsy review of infective endocarditis. Am J Clin Pathol. 2012;138:A260.

44. Guerrero M, Álvarez B, Manzarbeitia F, Renedo G. Infective endocarditis at autopsy: a review of pathologic manifestations and clinical correlates. Medicine. 2012;91:152-64.

45. Abegaz T, Bahagavathula A, Gebreyohannes E, Mekonnen A, Abebe T. Short-and long-term outcomes in infective endocarditis patients: a systematic review and meta-analysis. Cardiovasc Disord. 2017;17:112.

46. Fernández-Hidalgo N, Almirante $B$, Tornos P, González-Alujas M, Planes $A$, Galiñanes $M$, et al. Immediate and long-term outcome of left-sided infective endocarditis. A 12-year prospective study from a contemporary cohort in a referral hospital. Clin Microbiol Infect. 2012;18:e522-30.

47. Toyoda N, Chikwe J, Itagaki S, Gelijns A, Adams D, Egorova N. Trends in infective endocarditis in California and New York state, 1998-2013. JAMA. 2017;317:1652-60.

48. Shih C, Chu H, Chao P, Lee Y, Kuo S, Li SY, et al. Long-term clinical outcome of major adverse cardiac events in survivors of infective endocarditis a nationwide population-based study. Circulation. 2014;130:1684-91.

49. Chen S, Chao T, Lin Y, Lo LW, Hu Y, Tuan T, et al. Cool seasons are related to poor prognosis in patients with infective endocarditis. Int $\mathrm{J}$ Biometeorol. 2012;56:973-81.

50. Boulay F, Berthier F, Sisteron O, Gendreike Y, Gibelin P. Seasonal variation in chronic heart failure hospitalizations and mortality in France. Circulation. 1999;100:280-6.

51. Martínez-Sellés M, Robles J, Prieto L, Serrano J, Muñoz R, Frades E, et al. Annual rates of admission and seasonal variations in hospitalizations for heart failure. Eur J Heart Fail. 2002;4:779-86.

52. Danai P, Sinha S, Moss M, Haber M, Martin G. Seasonal variation in the epidemiology of sepsis. Crit Care Med. 2007;35:410-5.

53. Marti-Soler H, Gonseth S, Gubelmann C, Stringhini S, Bovet P, Chen $\mathrm{PC}$, et al. Seasonal variation of overall and cardiovascular mortality: a study in 19 countries from different geographic locations. PLoS One. 2014;9:1-13.

54. Rau R, Bohk-Ewald C, Muszyńska M, Vaupel J. Seasonality of causes of death. In: Rau R, Bohk-Ewald C, Muszyńska MM, Vaupel JW, editors. Visualizing mortality dynamics in the lexis diagram. Berlin: Springer. 2018; p. 99-122.

55. Oestergaard L, Schmiegelow M, Bruun N, Skov R, Petersen A, Andersen $\mathrm{P}$, et al. The associations between socioeconomic status and risk of staphylococcus aureus bacteremia and subsequent endocarditis - a Danish nationwide cohort study. BMC Infect Dis. 2017;17:589.

56. Dowell SF. Seasonal variation in host susceptibility and cycles of certain infectious diseases. Emerg Infect Dis. 2001;7:369-74.

57. Demas G, Bartness T, Nelson R, Drazen D. Photoperiod modulates the effects of norepinephrine on lymphocyte proliferation in Siberian hamsters. Am J Physiol Regul Integr Comp Physiol. 2003;285:R873-9.

58. Finkelhor R, Cater G, Qureshi A. Seasonal diagnosis of echocardiographically demonstrated endocarditis. Chest. 2005;128:2588-92. 